\title{
Isolated intermediate-depth seismicity north of the Izu peninsula, Japan: implications for subduction of the Philippine Sea Plate
}

\author{
Junichi Nakajima*
}

\begin{abstract}
The subduction of the Philippine Sea (PHS) Plate toward the north of Izu peninsula, Japan, is of great interest because intraslab seismicity is absent where the buoyant Izu volcanic arc has been subducting over the past 15 Myr. This study analyzes 42 earthquakes in an isolated seismic cluster that occurred $\sim 100 \mathrm{~km}$ north of Izu peninsula at depths of 40-90 km and discusses seismogenesis in the context of plate subduction. We picked $P$ - and S-wave arrival times of earthquakes to produce a complete hypocenter catalogue, carried out double-difference event relocations, and then determined focal mechanism solutions of 7 earthquakes from $P$-wave polarity data. Based on the focal mechanism solution, the largest earthquake (M3.1) is interpreted as a thrust earthquake along the upper surface of the PHS Plate. Locations of other earthquakes relative to the largest event suggest that most earthquakes occur within the subducting PHS Plate. Our results suggest that the PHS Plate north of Izu peninsula has temperatures low enough to facilitate thrust and intraslab earthquakes at depths of 60-90 km. Earthquakes are likely to occur where pore pressures are locally high, which weakens pre-existing faults. The presence of the intermediate-depth seismic cluster indicates the continuous subduction of the PHS Plate toward the north of Izu peninsula without any disruption.
\end{abstract}

Keywords: Earthquake, Slab temperature, Dual subduction, Volcanic ridge

\section{Introduction}

In central Japan, the relatively young Philippine Sea (PHS) Plate is being subducted at the Sagami and Nankai Troughs, while the older Pacific Plate is being subducted below the PHS Plate (Fig. 1). The PHS Plate located east of the Izu volcanic arc formed before $40 \mathrm{Ma}$, while that located west of the arc formed as a back-arc basin from 27 to $15 \mathrm{Ma}$ (e.g., Okino et al. 1999). The Izu volcanic ridge on the PHS Plate, which formed in an intraoceanic setting, has been colliding with central Japan at the western margin of the Kanto district since $15 \mathrm{Ma}$ (e.g., Soh et al. 1998). Geological observations have revealed the collision and partial accretion of a tectonic slice of buoyant Izu-Bonin arc (e.g., Taira et al. 1998), while seismological observations suggest that only the lower crust and

*Correspondence: nakajima@geo.titech.ac.jp Department of Earth and Planetary Sciences, School of Science, Tokyo Institute of Technology, Meguro-ku, Japan mantle of the Izu volcanic arc are subducting (e.g., Arai et al. 2014).

The subduction of the PHS Plate beneath Kanto has been inferred to a depth of $\sim 60 \mathrm{~km}$ from the occurrence of thrust earthquakes including small repeating earthquakes (red squares in Fig. 1) (Uchida et al. 2010a) and to $\sim 120 \mathrm{~km}$ from seismicity and the presence of highvelocity anomalies that are interpreted as the mantle of the PHS Plate (e.g., Ishida 1992; Matsubara et al. 2005; Hori 2006; Wu et al. 2007; Nakajima et al. 2009; Uchida et al. 2010a). In contrast, the presence of the PHS Plate beneath Tokai can be confirmed by intensive seismicity that deepens toward the north, to a maximum depth of $\sim 60 \mathrm{~km}$ (Fig. 2a) (e.g., Nakajima and Hasegawa 2007). However, seismicity is almost absent northwest of Izu peninsula (Fig. 2a), and there is an ongoing debate about whether the PHS Plate is continuous between Kanto and Tokai (e.g., Ishida 1992).

Since October 1997, the Japan Meteorological Agency (JMA) has processed waveform data from seismograph 


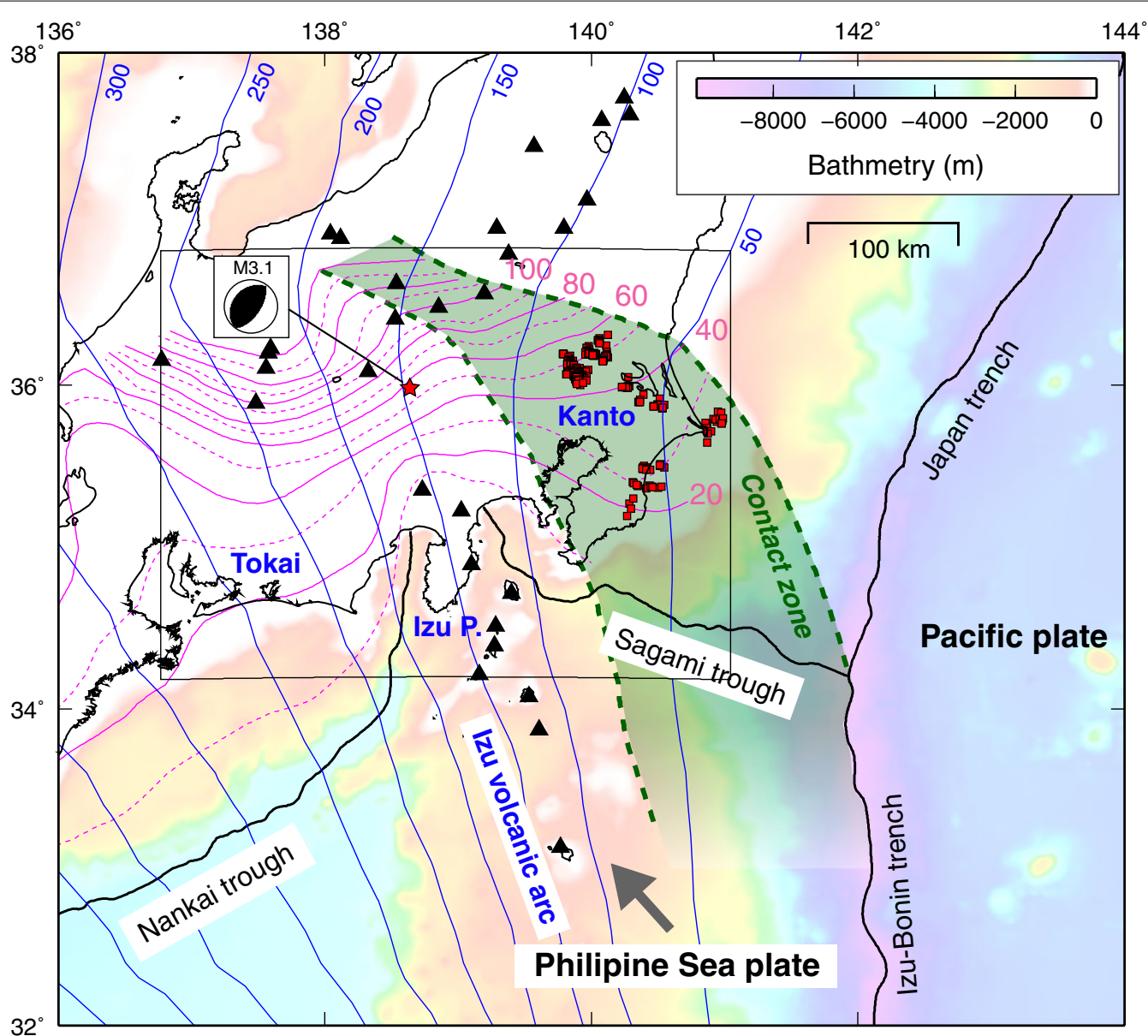

Fig. 1 Tectonic setting of central Japan with seafloor topography. Pink and blue lines denote iso-depth contours of the PHS Plate (Hirose et al. 2008; Nakajima et al. 2009) and Pacific Plate (Nakajima et al. 2009), respectively. Green shading represents an area where the bottom of the PHS Plate is in contact with the upper surface of the Pacific Plate (Nakajima et al. 2009; Uchida et al. 2009). Black triangles denote active volcanoes. Red squares represent the epicenters of thrust earthquakes that occurred along the upper surface of the PHS Plate. The red star denotes the epicenter of the M3.1 earthquake analyzed in this study. The focal mechanism of the M3.1 earthquake, as determined by the Japan Meteorological Agency (JMA), is shown in an equal-area lower-hemisphere projection. Gray arrow shows the relative plate motion of the PHS Plate with respect to the continental plate. The rectangle shows the area highlighted in Fig. 2a

stations throughout the Japanese islands to produce a comprehensive seismic catalogue (the JMA unified catalogue). This catalogue has reported several earthquakes located $\sim 100 \mathrm{~km}$ north of Izu peninsula at depths of $40-90 \mathrm{~km}$, forming an isolated cluster of seismic activity (seismicity in blue rectangles in Fig. 2a, b). Matsubara et al. (2008) first pointed out the occurrence of an M3.1 earthquake in 2006 at a depth of $61 \mathrm{~km}$ and interpreted that the earthquake occurred on the upper surface of the PHS Plate. Nakajima et al. (2009) followed Matsubara et al's interpretation and proposed a continuous plate subduction model between Kanto and Tokai without any disruption or splitting (pink contours in Fig. 1). This study analyzes small earthquakes in the isolated seismic cluster and discusses their seismogenesis in the context of subduction of the PHS Plate.

\section{Data and methods}

An isolated seismic cluster is located $\sim 100 \mathrm{~km}$ north of Izu peninsula at focal depths of $40-90 \mathrm{~km}$. The JMA unified catalogue includes 42 earthquakes in this region from October 1997 to March 2017, with the largest event (M3.1) on January 1, 2006; the 42 earthquakes do not occur in swarms, but rather are evenly distributed over time (Fig. 2c). The spatial distribution of the hypocenters shows that they tend to become deeper toward the north (Fig. 3a).

For the 24 earthquakes that occurred after 2004, waveform data were downloaded from the Hi-net Web site (http://www.hinet.bosai.go.jp/?LANG=en) and $P$ - and $S$-wave arrival times were manually picked at stations whose arrival times were not determined by the JMA, to produce a complete phase arrival catalogue. $S-P$ times 

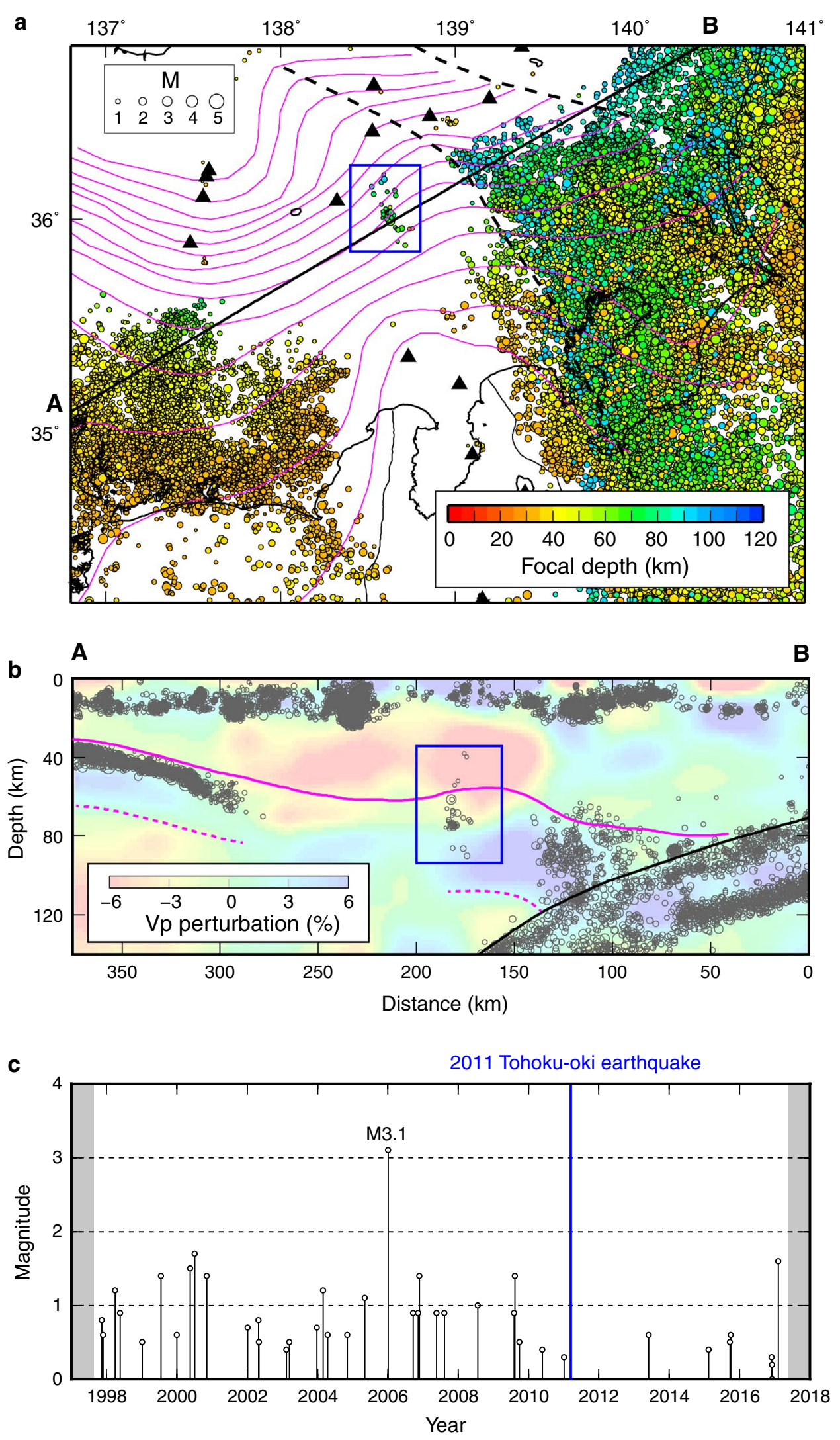
(See figure on previous page.)

Fig. 2 a Distribution of earthquakes at depths of 30-100 km from October 1997 to May 2017. Colors and sizes of circles are proportional to focal depths and earthquake magnitudes, respectively. Dashed lines denote the western and northeastern boundaries of the slab contact zone. The isolated cluster of seismicity analyzed in this study is bounded by the blue rectangle. Line A-B is a profile along which a vertical cross section is shown in b. Other symbols are the same as in Fig. 1. b Vertical color-shaded cross section of $P$-wave velocity perturbations (Nakajima et al. 2009) along line A-B and seismicity (gray circles) within $10 \mathrm{~km}$ of the profile. Pink and black lines represent the upper surfaces of the PHS and Pacific Plates, respectively. Pink dashed line shows the bottom of the PHS Plate inferred from the distribution of high-velocity anomalies. c Magnitude versus time plot of 42 earthquakes that occurred in the area indicated by blue rectangles in $\mathbf{a}$ and $\mathbf{b}$. The origin time of the 2011 Tohoku-Oki earthquake is indicated by a vertical blue line. Shaded zones at both ends of the panel denote unanalyzed periods

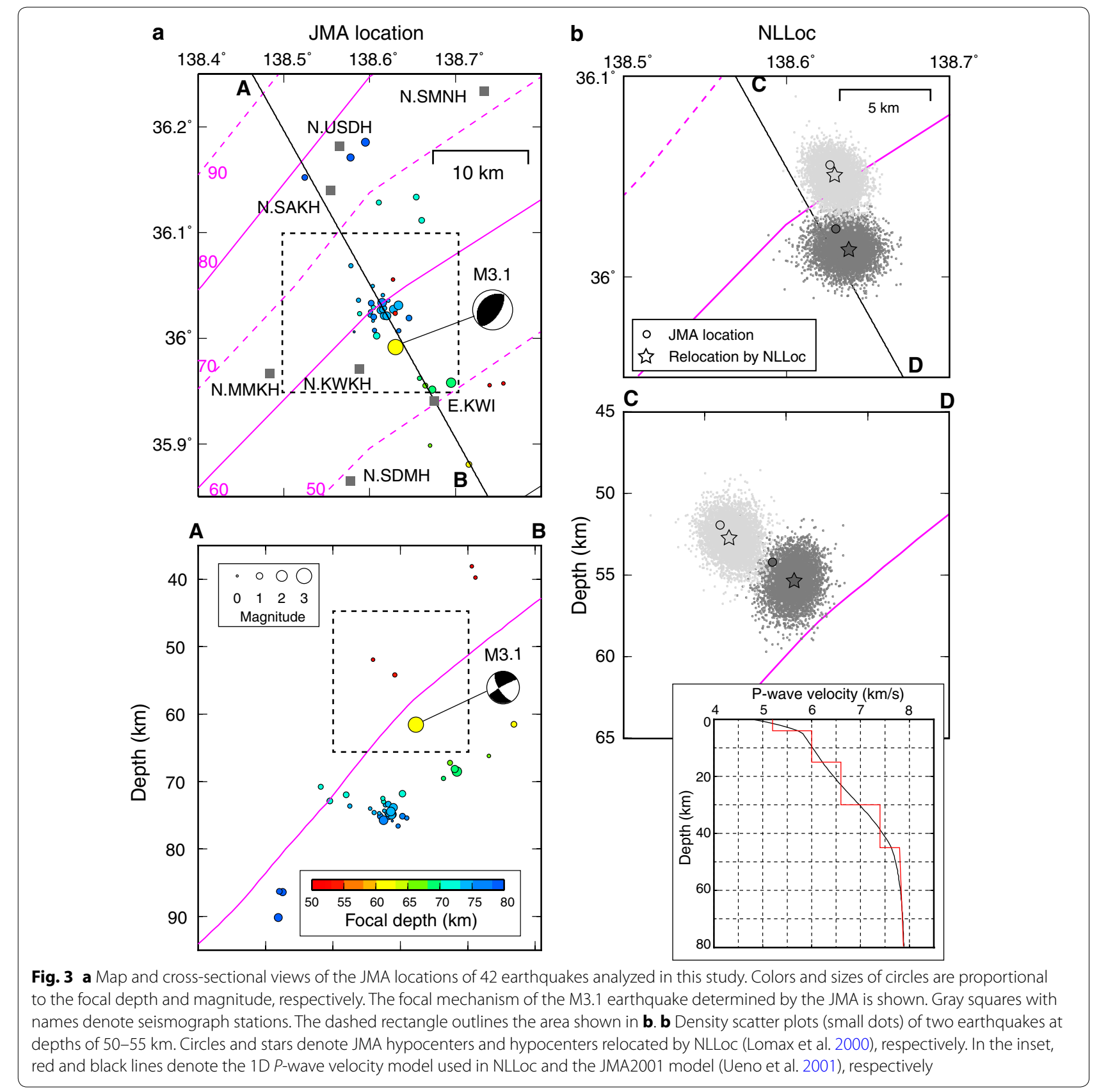


at stations with epicentral distances of $\leq 10 \mathrm{~km}$ are positively correlated with the focal depths determined by the JMA (Fig. 4a). Examples of waveforms recorded at station N.KWKH, the nearest station to the epicenter of the M3.1 earthquake (see Fig. 3), show that the onsets of $P$ - and $S$-waves are clear on the vertical and horizontal components, respectively, and that arrival times can be identified with uncertainties of $<0.1 \mathrm{~s}$ for $P$-waves and $<0.3 \mathrm{~s}$ for $S$-waves (Fig. $4 \mathrm{~b}$ ). We are therefore confident that the depth extent of the 42 earthquakes over $50 \mathrm{~km}$ is constrained well by $S-P$ times determined from high-quality waveforms. Since waveforms of the earthquakes include high-frequency $(>10 \mathrm{~Hz})$ energy, these earthquakes cannot be deep low-frequency earthquakes, which have a dominant frequency of $2-4 \mathrm{~Hz}$ and virtually no energy above $8 \mathrm{~Hz}$ (e.g., Hasegawa and Yamamoto 1994; Ukawa 2005).

To improve the relative hypocenter locations, the earthquakes were relocated with the double-difference relocation algorithm (hypoDD) (Waldhauser and Ellsworth 2000) using phase-picked differential travel times with a maximum earthquake pair separation of $10 \mathrm{~km}$. A total of $3823 P$-wave and $3726 S$-wave differential time data were obtained at 59 stations. Forty of the initial 42 earthquakes were relocatable (Figs. 3, 5). The standard deviations of the hypocentral shifts of relocated earthquakes with respect to the initial JMA locations were 1.2, 1.3 , and $1.0 \mathrm{~km}$ in latitude, longitude, and depth, respectively. Two earthquakes relocated to depths of $50-55 \mathrm{~km}$ were $5-10 \mathrm{~km}$ shallower than the upper surface of the PHS Plate. The missing earthquakes were the two shallowest earthquakes, with JMA focal depths of $\sim 40 \mathrm{~km}$.

Since double-difference relocation does not significantly improve the absolute locations, the absolute errors of the two earthquakes at $50-55 \mathrm{~km}$ were estimated by probabilistic, nonlinear hypocenter relocation (NLLoc) (Lomax et al. 2000). Unlike linear approaches, NLLoc provides comprehensive uncertainty and relocation information, represented by an a posteriori probability density function. We first constructed a one-dimensional (1D) layered $P$-wave velocity model (red line in the inset in Fig. 3b) based on the JMA2001 velocity model (Ueno et al. 2001) and then relocated the two earthquakes using manually picked $P$ - and $S$-wave arrival times assuming a constant $\mathrm{Vp} / \mathrm{Vs}$ ratio of 1.73 . Relocated results showed that the two earthquakes deepened slightly with respect to the JMA locations, but are still located $\sim 5 \mathrm{~km}$ above the upper boundary of the PHS Plate (Fig. 3b).

The JMA determined the focal mechanism of the M3.1 earthquake to be reverse faulting (Fig. 1). To investigate the focal mechanism solutions of other small earthquakes, the $P$-wave polarities of the 24 earthquakes after 2004 were picked and the focal mechanisms were determined for earthquakes with 10 or more polarities using the method of Hardebeck and Shearer (2002). As a result, focal mechanisms were obtained for seven additional earthquakes with polarity errors of $<15 \%$. Six of the seven focal mechanisms show reverse or strike-slip faulting (Fig. 5d).

\section{Results and discussion}

The relocated hypocenters do not differ substantially from the initial JMA locations (Figs. 3, 5), but seismicity located at $\sim 75 \mathrm{~km}$ depth in the central part of the seismic cluster was tightened after relocation. The M3.1 earthquake was relocated to $63 \mathrm{~km}$. One of the nodal planes of the M3.1 earthquake has a dip of $30^{\circ}$, which is roughly consistent with the dip of the upper surface of the PHS Plate (Fig. 5b). The slip vector of the M3.1 earthquake $\left(\mathrm{N} 40^{\circ} \mathrm{W}\right)$ is sub-parallel to the relative plate motion between the PHS Plate and the overlying continental plates $\left(\mathrm{N} 48^{\circ} \mathrm{W}\right.$ for the North American Plate; N54 ${ }^{\circ} \mathrm{W}$ for the Okhotsk Plate) (Kreemer et al. 2014). Most events occur deeper than the M3.1 earthquake, and none of the deeper earthquakes has a thrust-type focal mechanism; therefore, a simple interpretation is that the M3.1 earthquake occurred along the upper surface of the PHS Plate, as assumed by Matsubara et al. (2008) and Nakajima et al. (2009), while other earthquakes occurred in the subducting PHS Plate.

One key to interpreting seismogenesis in the subducting PHS Plate is the thermal regime, because thrust (interplate) and mantle earthquakes are considered to occur at temperatures of $<350{ }^{\circ} \mathrm{C}$ (e.g., Hyndman et al. 1997) and < 600-650 ${ }^{\circ} \mathrm{C}$ (e.g., McKenzie et al. 2005; Braunmiller and Nábělek 2008), respectively, above which materials are ductile. Numerical simulations of PHS Plate subduction suggest that temperatures at the locations of deep thrust earthquakes at 50-60 km beneath Kanto (red squares in Fig. 1) and the M3.1 earthquake are well above $400{ }^{\circ} \mathrm{C}$ (Yoshioka et al. 2015; Wada and He 2017), higher than the critical temperature of thrust earthquakes. Existing thermal models assume that the age of the incoming PHS Plate is $20-40 \mathrm{Ma}$ and pre-subduction plate temperatures are calculated with a 1D cooling model of an oceanic plate (Ji et al. 2017; Wada and He 2017). However, as a result of subduction of the Pacific Plate beneath the PHS Plate along the Izu-Bonin trench, the fore-arc of the incoming PHS Plate is cooled long before its subduction by the underlying cold Pacific Plate (Fig. 1). This effect, which is not fully modeled in the numerical simulations, may lower pre-subduction temperatures significantly in the fore-arc of the PHS Plate relative to the initial plate temperatures prescribed in the numerical models. If this is the case, actual temperature conditions of the slab surface may be much lower than those modeled in 


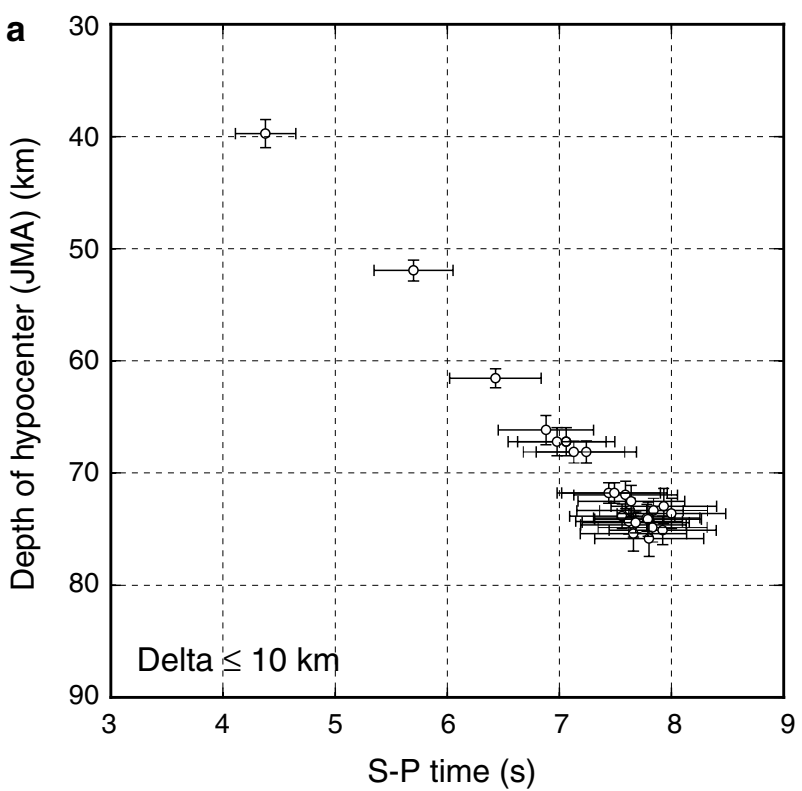

b N.KWKH (UD) Bandpass filter: $2-16 \mathrm{~Hz}$

$1 \mathrm{~s} \longrightarrow$

\begin{tabular}{|c|c|}
\hline \\
\hline \multicolumn{2}{|r|}{ 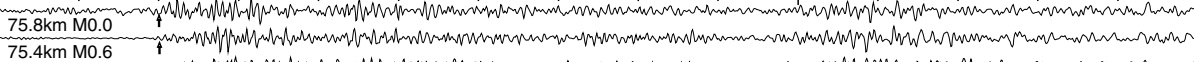 } \\
\hline \multirow{2}{*}{\multicolumn{2}{|c|}{ 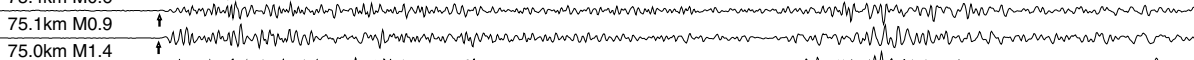 }} \\
\hline & \\
\hline \multicolumn{2}{|l|}{$\begin{array}{l}75.0 \mathrm{~km} \mathrm{M1.4} \\
74.8 \mathrm{~km} \mathrm{M0.6}\end{array}$} \\
\hline \multicolumn{2}{|r|}{ S } \\
\hline \multicolumn{2}{|r|}{ 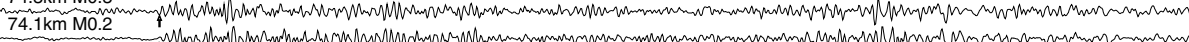 } \\
\hline \multicolumn{2}{|r|}{ 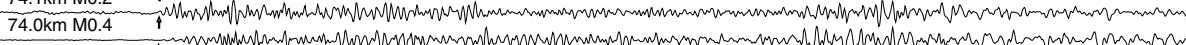 } \\
\hline \multicolumn{2}{|r|}{ 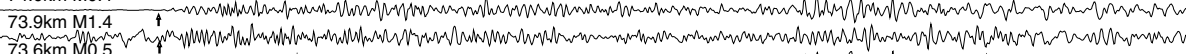 } \\
\hline \multicolumn{2}{|l|}{$73.6 \mathrm{~km}$ MO.5 } \\
\hline \multicolumn{2}{|l|}{$73.3 \mathrm{~km} \mathrm{M0.9}$} \\
\hline \multicolumn{2}{|l|}{$72.5 \mathrm{~km} \mathrm{M0} 0.5$} \\
\hline \multicolumn{2}{|l|}{$\begin{array}{l}72.5 \mathrm{~km} \text { M0.5 } \\
72.0 \mathrm{~km} \text { M0.9 }\end{array}$} \\
\hline \multicolumn{2}{|l|}{$71.8 \mathrm{~km} \mathrm{M1} .0$} \\
\hline \multicolumn{2}{|l|}{$68.1 \mathrm{~km} \mathrm{M1.2}$} \\
\hline \multicolumn{2}{|l|}{$67.2 \mathrm{~km} \mathrm{M0.7}$} \\
\hline \multicolumn{2}{|l|}{$\begin{array}{l}6.6 \mathrm{~km} \mathrm{M} 0.3 \\
61.5 \mathrm{~km} M 3.1\end{array}$} \\
\hline $61.5 \mathrm{~km} \mathrm{M0.9}$ & Tithromens \\
\hline & whmonnm \\
\hline
\end{tabular}

$\mathrm{P}$ pick

N.KWKH (NS) Bandpass filter: 2-16 Hz

\begin{tabular}{|c|}
\hline Chr \\
\hline 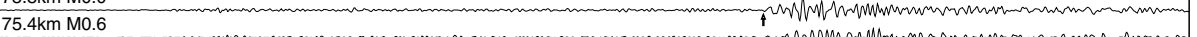 \\
\hline 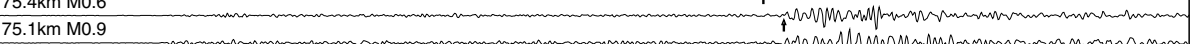 \\
\hline 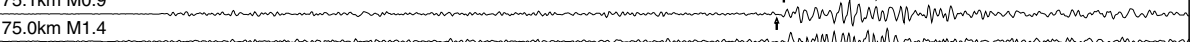 \\
\hline 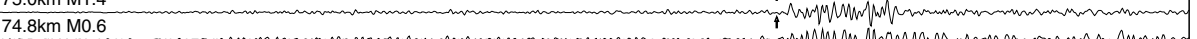 \\
\hline 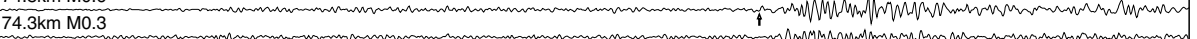 \\
\hline 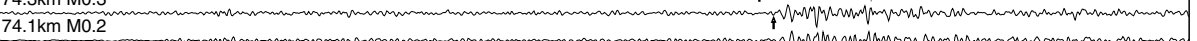 \\
\hline 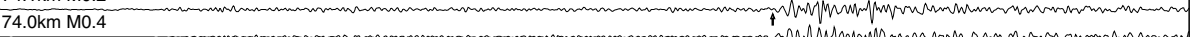 \\
\hline 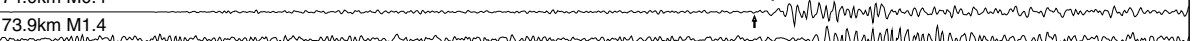 \\
\hline 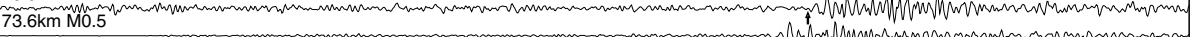 \\
\hline 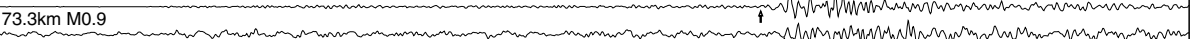 \\
\hline 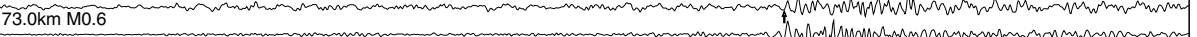 \\
\hline Mhom \\
\hline 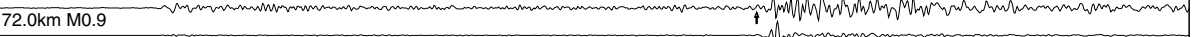 \\
\hline $71.8 \mathrm{~km} \mathrm{M1.0}$ \\
\hline $68.1 \mathrm{~km} \mathrm{M1.2}$ \\
\hline $67.2 \mathrm{~km} \mathrm{M0.7}$ \\
\hline $66.2 \mathrm{~km} \mathrm{M0.3}$ \\
\hline $61.5 \mathrm{~km} \mathrm{M} 3.1$ \\
\hline $61.5 \mathrm{~km} \mathrm{M0.9}$ \\
\hline A Th \\
\hline
\end{tabular}


(See figure on previous page.)

Fig. 4 a Distribution of focal depths with respect to $S-P$ times observed at stations with epicentral distances of $<10 \mathrm{~km}$. Error bars in focal depths are taken from the JMA unified catalogue; error bars for S-P times are calculated from uncertainties in each $P$ - and S-wave pick. b Examples of waveforms of UD and NS components at station N.KWKH. Waveforms are band-passed from 2 to $16 \mathrm{~Hz}$ and then aligned with manually picked $P$-wave arrival times. $P$ - and S-wave arrival times are indicated by arrows on the UD and NS components, respectively. Focal depths and magnitudes are indicated in the leftmost side below each waveform. Waveforms are not shown for earthquakes without $P$-wave picks at this station

a

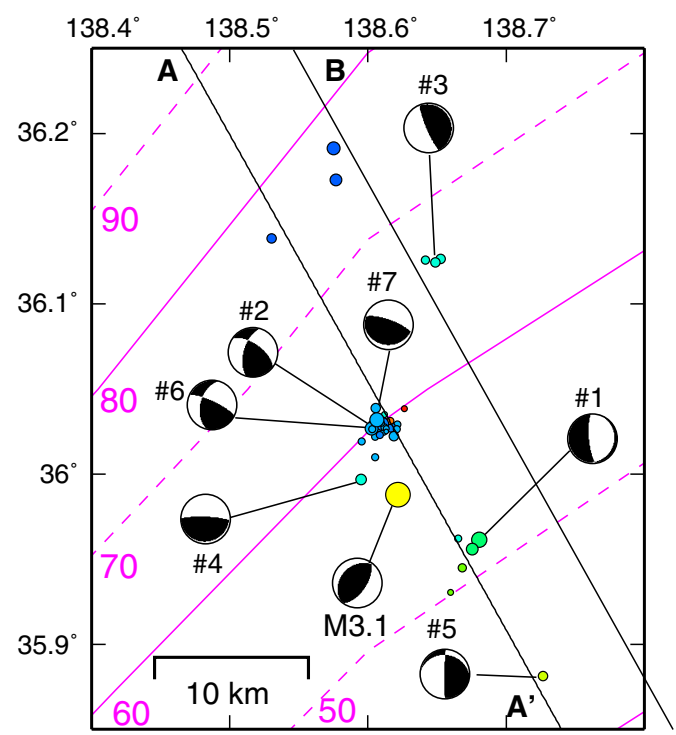

b

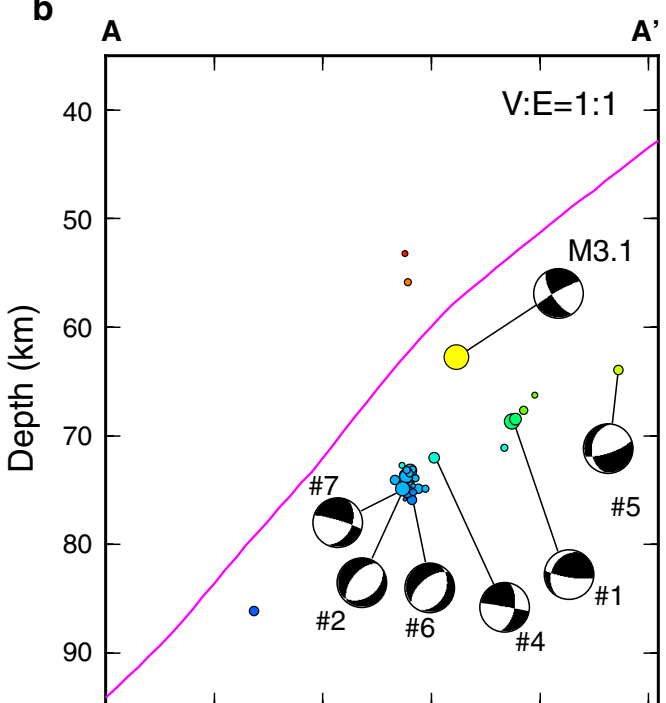

d

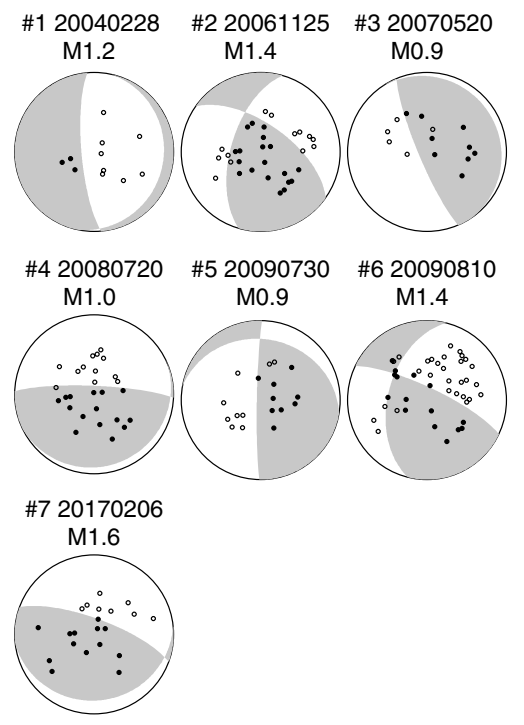

B'

C

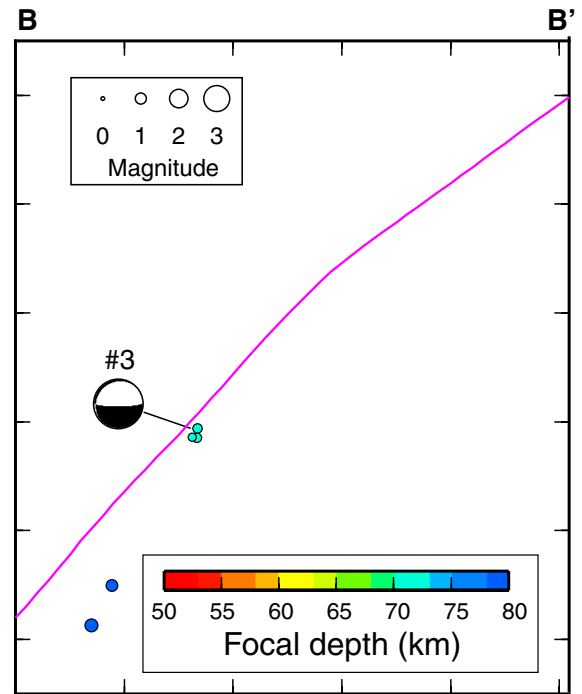

Fig. 5 a Map showing the distribution of 40 earthquakes relocated with hypoDD (see text for procedural details). Available earthquake focal mechanisms (\#1-\#7 and M3.1 earthquake) are shown in equal-area lower-hemisphere projections. Two lines, A-A' and B-B', are profiles along which cross sections are shown in $\mathbf{b}$ and $\mathbf{c}$, respectively. $\mathbf{b}$ Vertical cross section of earthquakes along line A-A', showing events within $3 \mathrm{~km}$ of the line. $\mathbf{c}$ As for $\mathbf{b}$, but for line B-B'. d Focal mechanism solutions of seven earthquakes (\#1-\#7) determined in this study. Filled and open circles indicate compressional and dilatational first motions, respectively. Magnitudes of earthquakes are shown above their respective beach ball plots

numerical simulations, and such low temperatures may trigger thrust earthquakes even at depths of 50-60 km, where the M3.1 earthquake (red star in Fig. 1) and deep thrust earthquakes beneath Kanto (red squares in Fig. 1) occurred. Numerical simulations of PHS Plate subduction in consideration of the pre-subduction cooling effect 
will aid our understanding of the seismogenesis of deep thrust earthquakes of the PHS Plate.

Our interpretation of the M3.1 earthquake at $63 \mathrm{~km}$ is a thrust earthquake along the upper surface of the PHS Plate, because the depth of the M3.1 earthquake is comparable to that of deep thrust earthquakes beneath Kanto $(50-60 \mathrm{~km})$ and the focal mechanism can be explained by shear slip on the PHS Plate. Considering the locations of other earthquakes relative to the M3.1 earthquake, the majority occur within $5-15 \mathrm{~km}$ from the slab surface. The pre-subduction crustal thickness of the fore-arc and sub-arc PHS Plate is estimated to be $7-25 \mathrm{~km}$ and shows marked spatial variations resulting from the evolutionary history of crustal structure (e.g., Kamimura et al. 2002; Takahashi et al. 2009; Kodaira et al. 2010). In addition, the crust of the PHS Plate is possibly thinned by an accretionary process at the collision zone (e.g., Taira et al. 1998; Arai et al. 2014). These complex evolution and subduction processes make it difficult to conclude whether earthquakes occur mainly in the subducting crust or the subducting mantle.

The seismic cluster analyzed in this study is distributed across an area of $30 \times 10 \mathrm{~km}$. The localization of seismicity surrounded by an aseismic portion of the slab suggests differences in the mechanical properties of the two regions. Since slab stress is unlikely to vary significantly in space on such length scales, it is postulated that the PHS slab is locally hydrated in the seismogenic region, thereby facilitating intermediate-depth earthquakes by fluid-related embrittlement (e.g., Hacker et al. 2003; Hasegawa and Nakajima 2017). Overpressurized fluids weaken fault strength and eventually induce the reactivation of pre-existing, variously oriented faults under differential stresses generated by subduction. Although it has been suggested that the PHS Plate beneath the Izu volcanic arc was dried as a result of the consumption of a large amount of fluid for melt production before subduction (Arai et al. 2014), the seismogenic region may have been locally hydrated before subduction and remained hydrated afterward.

The hypocenters relocated by NLLoc show that the absolute location errors of two earthquakes at depths of $50-55 \mathrm{~km}$ are $<5 \mathrm{~km}$ (Fig. 3b), suggesting that they occurred in the uppermost mantle; the depth of the continental Moho in the region is estimated to be $\sim 40 \mathrm{~km}$ (Katsumata 2010). Mantle earthquakes are not usual, but earthquakes above the subducting plate are locally observed down to a depth of $\sim 60 \mathrm{~km}$ in NE Japan (Uchida et al. 2010b). Temperatures around mantle earthquakes in NE Japan are estimated to be $400{ }^{\circ} \mathrm{C}$ (e.g., Wada et al. 2015), which is well below the $600-650{ }^{\circ} \mathrm{C}$ critical temperature of mantle earthquakes (e.g., McKenzie et al. 2005; Braunmiller and Nábělek 2008). Since the estimated values of surface heat flow are not very high above the seismic cluster (Yoshioka et al. 2015) and the slab surface temperatures are likely to be $<350{ }^{\circ} \mathrm{C}$ at the location of the M3.1 earthquake, temperatures $5-10 \mathrm{~km}$ above the slab surface might be low enough for mantle earthquakes to occur at 50-60 km depth. Such earthquakes are likely to be facilitated by slab-derived fluids in a spot where permeability is low and pore fluid pressures can be enhanced to nearlithostatic values to bring the system into brittle failure.

A volume of intense seismic activity isolated from nearby seismicity is known as an earthquake nest: One famous example is the Bucaramanga Nest in Colombia at depths of 145-165 km. The Bucaramanga Nest includes normal and reverse fault earthquakes with similar waveforms, which are interpreted as repeating ruptures on the same fault or sub-parallel faults with reserved slip directions (e.g., Prieto et al. 2012). In the Pacific slab beneath NE Japan, nest-like seismicity is observed at a depth of $\sim 155 \mathrm{~km}$ (Nakajima et al. 2013), and the seismicity includes tensional earthquakes located $1 \mathrm{~km}$ above compressional earthquakes. Nakajima et al. (2013) suggested that eclogitization-related stresses cause local tension within a volume of down-dip compressional stresses in the slab crust. Even though a pair of tensional and compressional earthquakes was not identified in the seismicity of this study at depths of $\sim 75 \mathrm{~km}$ (Fig. 5), the lateral extent of the seismicity is comparable to that of the nestlike seismicity in NE Japan. The occurrences of larger earthquakes in this cluster would enable us to increase the number of focal mechanisms and to better constrain relative earthquake locations. Further studies of this cluster and other nests at intermediate depths will improve our understanding of the genesis of intermediate-depth earthquakes.

\section{Conclusions}

We analyzed an isolated cluster of seismicity north of Izu peninsula in a depth range of $40-90 \mathrm{~km}$, relocated 40 earthquakes by hypoDD using catalogue-derived arrival time differences, and determined focal mechanism solutions of seven earthquakes from $P$-wave polarity data. A total of 37 earthquakes occurred in the subducting PHS Plate and 2 occurred in the overlying mantle. We interpret the M3.1 earthquake as a thrust earthquake. Although there are no observations other than the focal mechanism to support the conclusion that the M3.1 earthquake occurred on the PHS Plate, earthquakes outside subducting plates at depths of $>60 \mathrm{~km}$ have yet to be observed beneath the Japanese islands. Therefore, it is concluded that the majority of the earthquakes in the isolated cluster are distributed in the PHS Plate, where temperatures are sufficiently low, pore fluid pressures are locally high, and earthquakes are consequently 
facilitated under the deviatoric stresses generated by plate subduction.

The seismic cluster analyzed in this study provides a direct observation supporting the subduction of the PHS Plate toward the north of Izu peninsula. However, the lateral extent of the seismic cluster is too small to update the iso-depth contours of the PHS Plate proposed in previous studies. High-resolution seismic tomography and waveform analysis, as well as the detection of smaller intraslab earthquakes north of Izu peninsula, will provide additional constraints on the subduction and continuity of the PHS Plate in this tectonically complex area.

\section{Abbreviation}

PHS: Philippine Sea.

\section{Acknowledgements}

We used arrival time data reported in the earthquake catalogue unified by the Japan Meteorological Agency and downloaded waveform data from the Hi-net Web site of the National Institute of Advanced Industrial Science and Technology. Discussions with A. Hasegawa were very fruitful. Constructive comments by two reviewers improved the manuscript. All the figures in this paper are plotted using GMT (Wessel and Smith 1998).

\section{Competing interests}

The author declares no competing interests.

\section{Data availability}

The data that support the findings of this study are available from the corresponding author on request.

\section{Funding}

JSPS KAKENHI Grant Numbers: JP16H04040, JP16H04071, and JP17K05626.

\section{Publisher's Note}

Springer Nature remains neutral with regard to jurisdictional claims in published maps and institutional affiliations.

Received: 19 October 2017 Accepted: 4 January 2018

Published online: 18 January 2018

\section{References}

Arai R, Iwasaki T, Sato H et al (2014) Contrasting subduction structures within the Philippine Sea plate: Hydrous oceanic crust and anhydrous volcanic arc crust. Geochem Geophys Geosyst 15:1977-1990. https://doi. org/10.1002/2014GC005321

Braunmiller J, Nábělek J (2008) Segmentation of the Blanco transform fault zone from earthquake analysis: complex tectonics of an oceanic transform fault. J Geophys Res 113:B07108. https://doi. org/10.1029/2007JB005213

Hacker BR, Peacock SM, Abers GA, Holloway SD (2003) Subduction factory 2. Are intermediate-depth earthquakes in subducting slabs linked to metamorphic dehydration reactions? J Geophys Res 108:2030. https:// doi.org/10.1029/2001JB001129

Hardebeck JL, Shearer PM (2002) A new method for determining first-motion focal mechanisms. Bull Seismol Soc Am 92:2264-2276. https://doi. org/10.1785/0120010200

Hasegawa A, Nakajima J (2017) Seismic imaging of slab metamorphism and genesis of intermediate-depth intraslab earthquakes. Prog Earth Planet Sci 4:12. https://doi.org/10.1186/s40645-017-0126-9

Hasegawa A, Yamamoto A (1994) Deep, low-frequency microearthquakes in or around seismic low-velocity zones beneath active volcanoes in northeastern Japan. Tectonophysics 233:233-252. https://doi. org/10.1016/0040-1951(94)90243-7

Hirose F, Nakajima J, Hasegawa A (2008) Three-dimensional velocity structure and configuration of the Philippine Sea slab beneath Kanto district, central Japan, estimated by double-difference tomography (in Japanese with English abstract). J Seismol Soc Jpn 60:123-138

Hori S (2006) Seismic activity associated with the subducting motion of the Philippine Sea plate beneath the Kanto district, Japan. Tectonophysics 417:85-100. https://doi.org/10.1016/j.tecto.2005.08.027

Hyndman RD, Yamano M, Oleskevich DA (1997) The seismogenic zone of subduction thrust faults. Isl Arc 6:244-260. https://doi. org/10.1111/j.1440-1738.1997.tb00175.x

Ishida M (1992) Geometry and relative motion of the Philippine Sea Plate and Pacific Plate beneath the Kanto-Tokai district, Japan. J Geophys Res 97:489-513. https://doi.org/10.1029/91JB02567

Ji Y, Yoshioka S, Manea VC et al (2017) Three-dimensional numerical modeling of thermal regime and slab dehydration beneath Kanto and Tohoku, Japan. J Geophys Res Solid Earth 122:332-353. https://doi. org/10.1002/2016JB013230

Kamimura A, Kasahara J, Shinohara M et al (2002) Crustal structure study at the IzU-Bonin subduction zone around $31^{\circ} \mathrm{N}$ : implications of serpentinized materials along the subduction plate boundary. Phys Earth Planet Inter 132:105-129. https://doi.org/10.1016/S0031-9201(02)00047-X

Katsumata A (2010) Depth of the Moho discontinuity beneath the Japanese islands estimated by travel time analysis. J Geophys Res 115:B04303. https://doi.org/10.1029/2008JB005864

Kodaira S, Noguchi N, Takahashi N et al (2010) Evolution from fore-arc oceanic crust to island arc crust: a seismic study along the Izu-Bonin fore arc. J Geophys Res 115:B09102. https://doi.org/10.1029/2009JB006968

Kreemer C, Blewitt G, Klein EC (2014) A geodetic plate motion and global strain rate model. Geochem Geophys Geosyst 15:3849-3889. https://doi. org/10.1002/2014GC005407

Lomax A, Virieux J, Volant P, Thierry-Berge C (2000) Probabilistic earthquake location in 3D and layered models. In: Thruber CH, Rabinowitz N (eds) Advances in seismic event location. Kluwer Acad, Norwell, pp 101-134

Matsubara M, Hayashi H, Obara K, Kasahara K (2005) Low-velocity oceanic crust at the top of the Philippine Sea and Pacific plates beneath the Kanto region, central Japan, imaged by seismic tomography. J Geophys Res 110:B12304. https://doi.org/10.1029/2005JB003673

Matsubara M, Obara K, Kasahara K (2008) Three-dimensional P- and S-wave velocity structures beneath the Japan Islands obtained by high-density seismic stations by seismic tomography. Tectonophysics 454:86-103. https://doi.org/10.1016/j.tecto.2008.04.016

McKenzie D, Jackson J, Priestley K (2005) Thermal structure of oceanic and continental lithosphere. Earth Planet Sci Lett 233:337-349. https://doi. org/10.1016/j.epsl.2005.02.005

Nakajima J, Hasegawa A (2007) Subduction of the Philippine Sea plate beneath southwestern Japan: slab geometry and its relationship to arc magmatism. J Geophys Res 112:B08306. https://doi. org/10.1029/2006JB004770

Nakajima J, Hirose F, Hasegawa A (2009) Seismotectonics beneath the Tokyo metropolitan area, Japan: effect of slab-slab contact and overlap on seismicity. J Geophys Res 114:B08309. https://doi.org/10.1029/2008JB006101

Nakajima J, Uchida N, Shiina T, Hasegawa A, Hacker BR, Kirby SH (2013) Intermediate-depth earthquakes facilitated by eclogitization-related stresses and $\mathrm{H}_{2} \mathrm{O}$. Geology 41:659-662. https://doi.org/10.1130/G33796

Okino K, Ohara Y, Kasuga S, Kato Y (1999) The Philippine Sea: new survey results reveal the structure and the history of the marginal basins. Geophys Res Lett 26:2287-2290. https://doi.org/10.1029/1999GL900537

Prieto GA, Beroza GC, Barrett SA, Lopez GA, Flores M (2012) Earthquake nests as natural laboratories for the study of intermediate-depth earthquake mechanics. Tectonophys 570-571:42-56. https://doi.org/10.1016/j. tecto.2012.07.019

Soh W, Nakayama K, Kimura T (1998) Arc-arc collision in the Izu collision zone, central Japan, deduced from the Ashigara Basin and adjacent Tanzawa Mountains. Isl Arc 7:330-341. https://doi. org/10.1111/j.1440-1738.1998.00193.x

Taira A, Saito S, Aoike K et al (1998) Nature and growth rate of the Northern Izu-Bonin (Ogasawara) arc crust and their implications for continental crust formation. Is| Arc 7:395-407. https://doi, org/10.1111/j.1440-1738.1998.00198.x 
Takahashi N, Kodaira S, Tatsumi Y et al (2009) Structural variations of arc crusts and rifted margins in the southern Izu-Ogasawara arc-back arc system. Geochem Geophys Geosyst 10:Q09X08. https://doi. org/10.1029/2008GC002146

Uchida N, Nakajima J, Hasegawa A, Matsuzawa T (2009) What controls interplate coupling? Evidence for abrupt change in coupling across a border between two overlying plates in the NE Japan subduction zone. Earth Planet Sci Lett 283:111-121. https://doi.org/10.1016/j.epsl.2009.04.003

Uchida N, Matsuzawa T, Nakajima J, Hasegawa A (2010a) Subduction of a wedge-shaped Philippine Sea plate beneath Kanto, central Japan, estimated from converted waves and small repeating earthquakes. J Geophys Res 115:B07309. https://doi.org/10.1029/2009JB006962

Uchida N, Kirby SH, Okada T et al (2010b) Supraslab earthquake clusters above the subduction plate boundary offshore Sanriku, northeastern Japan: Seismogenesis in a graveyard of detached seamounts? I Geophys Res 115:B09308. https://doi.org/10.1029/2009JB006797

Ueno H, Hatakeyama S, Aketagawa T, Funasaki J, Hamada N (2001) Improvement of hypocenter determination procedures in the Japan Meteorological Agency (in Japanese with English abstract). Q J Seismol 65:123-134

Ukawa M (2005) Deep low-frequency earthquake swarm in the mid crust beneath Mount Fuji (Japan) in 2000 and 2001. Bull Volcanol 68:47-56. https://doi.org/10.1007/s00445-005-0419-5

Wada I, He J (2017) Thermal structure of the Kanto region, Japan. Geophys Res Lett 44:7194-7202. https://doi.org/10.1002/2017GL073597
Wada I, He J, Hasegawa A, Nakajima J (2015) Mantle wedge flow pattern and thermal structure in Northeast Japan: effects of oblique subduction and 3-D slab geometry. Earth Planet Sci Lett 426:76-88. https://doi. org/10.1016/j.epsl.2015.06.021

Waldhauser F, Ellsworth WL (2000) A double-difference earthquake location algorithm: method and application to the Northern Hayward Fault, California. Bull Seismol Soc Am 90:1353-1368. https://doi. org/10.1785/0120000006

Wessel P, Smith WHF (1998) New, improved version of tge generic mapping tools released. EOS Trans AGU 79:579

Wu F, Okaya D, Sato H, Hirata N (2007) Interaction between two subducting plates under Tokyo and its possible effects on seismic hazards. Geophys Res Lett 34:L18301. https://doi.org/10.1029/2007GL030763

Yoshioka S, Takagi R, Matsumoto T (2015) Relationship between temperatures and fault slips on the upper surface of the subducting Philippine Sea plate beneath the Kanto district, central Japan. Geophys J Int 201:878890. https://doi.org/10.1093/gji/ggv032

\section{Submit your manuscript to a SpringerOpen ${ }^{\odot}$ journal and benefit from:}

- Convenient online submission

- Rigorous peer review

- Open access: articles freely available online

- High visibility within the field

- Retaining the copyright to your article

Submit your next manuscript at $>$ springeropen.com 